\title{
Biosorptive Removal of Zinc from Aqueous Solution by Algerian Calotropis procera Roots
}

\author{
Bahia Meroufel ${ }^{1,2}{ }^{*}$, Mohamed Amine Zenasni1,2, André Merlin², Béatrice George ${ }^{2}$ \\ ${ }^{1}$ Laboratory of Valorization of Vegetal Resources and Food Security (VRVSA), Bechar University, Bechar, Algeria \\ ${ }^{2}$ Laboratory of Studies and Research on Material Wood (LERMAB), University of Lorraine, Nancy, France \\ Email: ${ }^{*}$ B.meroufel@gmail.com
}

Received 26 June 2015; accepted 24 July 2015; published 28 July 2015

Copyright (C) 2015 by authors and Scientific Research Publishing Inc.

This work is licensed under the Creative Commons Attribution International License (CC BY). http://creativecommons.org/licenses/by/4.0/

(c) (i) Open Access

\begin{abstract}
Potentially toxic trace elements, such as zinc, with high levels in water are very serious problems in many places around the world, sometimes in relation to natural sources and in other cases to anthropogenic ones. Adsorption process is among the most effective techniques for removing of many heavy metal ions from different types of water. In this study, an attempt has been made to investigate the efficiency of Calotropis procera roots (CP) in removing of $\mathrm{Zn}$ (II) from aqueous solution by using batch mode technique. During the removal process, the effects of solution $\mathrm{pH}, \mathrm{Zn}$ concentrations and contact time on adsorption efficiency by CP roots were studied. Experimental equilibrium data were analyzed by the Langmuir and Freundlich isotherm models. The results showed that the best fit was achieved with the Langmuir isotherm equation with maximum adsorption capacity of $9.69 \mathrm{mg} / \mathrm{g}$. The biosorption of $\mathrm{Zn}$ (II) was a fast process and followed the pseudo-second-order kinetic.
\end{abstract}

\section{Keywords}

Calotropis procera, Zn(II), Adsorption Kinetics, Adsorption Isotherms

\section{Introduction}

Global developments directed towards making human life increasing comfortable have greatly increased industrialization and urbanization. However, this trend has damaged the environment alarmingly, mainly due to the generation of a large amount of hazardous waste and the pollution of usable surface water. The major pollutants

*Corresponding author.

How to cite this paper: Meroufel, B., Zenasni, M.A., Merlin, A. and George, B. (2015) Biosorptive Removal of Zinc from Aqueous Solution by Algerian Calotropis procera Roots. Journal of Environmental Protection, 6, 735-743. 
in wastewater are heavy metals such as lead, zinc, copper, cadmium, mercury, chromium and arsenic. These metals accumulate in living tissues/organs and can cause accumulative poisoning and serious health problems such as cancer and brain damage [1].

There are numerous methods which are currently employed to remove these metals from aqueous environment. Some of these methods are chemical precipitation and sludge separation, chemical oxidation or reduction, ion exchange, reverse osmosis, membrane separation, electrochemical treatment and evaporation. Biosorption as a wastewater bioremediation process has been found to be an economically feasible alternative for metal removal. This method offers the advantages of low operating cost, minimizing secondary pollution and high efficiency in wastes [2] [3]. The use of nonliving biomass in biosorption is more practical and advantageous because living biomass cells often require the addition of fermentation media which increases the biological oxygen demand or chemical oxygen demand in the effluent. In addition, non-living biomass is not affected by the toxicity of the metal ions, and they can be subjected to different chemical and physical treatment techniques to enhance their performance.

The aim of the present work was to study the effect of some environmental parameters such as solution $\mathrm{pH}$, initial Zn(II) concentration and contact time on the ability of Calotropis procera roots to biosorb Zn(II) ions from aqueous solutions.. Calotropis procera (Asclepiadaceae), commonly known as swallow wart, Sodom apple or milk weed, is a glabrous or hairy laticiferous shrub or small tree, found in tropical and subtropical Asia and Africa [4]. The leaves are widely used in Nigeria for coagulation of milk in preparing cheese [5] and the roots are traditionally used in India to treat diarrhea, cough, skin diseases, rheumatism, as an expectorant and emetic [6] [7].

\section{Materials and Methods}

\subsection{Adsorbent}

The roots of Calotropis procera studied in this paper were taken from the local shrub roots in Oued Ksiksous in province Bechar (South West of Algeria). These roots were washed with deionized water to remove any dirt. They were dried in an oven at $60^{\circ} \mathrm{C}$ for two days. The dried roots were ground and sieved through a sieve of 100 $\mu \mathrm{m}$ and then stored in a container. The sample of roots powder was characterized by using infrared (FT-IR) and scanning electron microscopic (SEM) techniques.

\subsection{Reagents}

All chemicals used were of analytical grade. Stock standard solution of $\mathrm{Zn}^{2+}$ has been prepared by dissolving the appropriate amount of $\mathrm{ZnSO}_{4}$ in deionized water. This stock solution was then diluted to specified concentrations. The $\mathrm{pH}$ of the system was adjusted using reagent grade $\mathrm{NaOH}$ and $\mathrm{HCl}$ respectively. All plastic sample bottles and glassware were cleaned, then rinsed with deionized water and dried at $60^{\circ} \mathrm{C}$ in a temperature controlled oven.

\subsection{Instrumentation}

The $\mathrm{pH}$ of all solution was measured by a TitraLab Instrument TIM800 Model pH meter. The adsorption experiments have been studied by batch technique using a thermostated shaker bath GFL-1083 Model. An Eppendorf 5702 Model digital centrifuge was used to centrifuge the samples. Zn(II) concentrations of solutions before and after adsorption were measured by using flame atomic absorption spectrophometer (Varian, SpectrAA-100, AAS).

The Fourier transform infrared (FT-IR) absorption spectra was recorded on $\mathrm{KBr}$ pressed pellets of the powdered sample in the range $4000-400 \mathrm{~cm}^{-1}$, using a Perkine-Elmer FTIR 2000 spectrophotometer.

Nanomorphology was characterized by scanning electron microscopy (SEM) which was carried out using Hitachi S-4800 equipped with energy dispersive spectrometry for chemical analysis (EDS) and operating at $15 \mathrm{kV}$ acceleration voltage.

\subsection{Adsorption Procedure}

Adsorption measurements were determined by batch experiments. The effect of contact time on the biosorption 
capacity of Calotropis procera roots was studied in the range 1 - $360 \mathrm{~min}$ at an initial concentration of $100 \mathrm{mg} / \mathrm{L}$. Adsorption kinetics was studied using an initial concentration of $100 \mathrm{mg} / \mathrm{L}$ with the adsorbent dosage of 0.1 $\mathrm{g} / 10 \mathrm{~mL}$ at $\mathrm{pH}$ 6.5. Adsorption isotherms were studied at various initial concentrations of $\mathrm{Zn}$ (II) ion in the range of $10-120 \mathrm{mg} / \mathrm{L}$ and the experiments were conducted at different constant temperatures in the range of $25^{\circ} \mathrm{C}$ $60^{\circ} \mathrm{C}$. The amount of $\mathrm{Zn}(\mathrm{II})$ adsorbed per unit mass of Calotropis procera roots was calculated by using the mass balance equation given in Equation (1) [8].

$$
q_{e}=\frac{\left(C_{0}-C_{e}\right) V}{m}
$$

where $q_{e}$ is the maximum adsorption capacity in $\mathrm{mg} / \mathrm{g}, C_{0}$ is the initial concentration and $C_{e}$ is the concentration at equilibrium of $\mathrm{Zn}(\mathrm{II})$ solution in $\mathrm{mg} / \mathrm{L}, V$ is the volume of the $\mathrm{Zn}(\mathrm{II})$ solution in $\mathrm{mL}$ and $m$ is the mass of $\mathrm{CP}$ roots in grams.

The sorption capacity at time $t, q_{t}(\mathrm{mg} / \mathrm{g})$ was obtained as Equation (2) [9]:

$$
q_{t}=\frac{\left(C_{0}-C_{t}\right) V}{m}
$$

where $C_{0}$ and $C_{t}(\mathrm{mg} / \mathrm{L})$ are the liquid phase concentrations of $\mathrm{Zn}(\mathrm{II})$ at initial and a given time $t, V$ is the solution volume and $\mathrm{m}$ the mass of $\mathrm{CP}$ roots $(\mathrm{g})$.

\section{Results and Discussion}

\subsection{Characterisation of Adsorbent}

Observation under a scanning electron microscope (SEM) in Figure 1 shows that grains of CP roots have amorphous structures; they are agglomerated in balls of different sizes, which can have cavities inside.

The FTIR Spectra of Calotropis procera roots, in the range of $400-4000 \mathrm{~cm}^{-1}$ was taken to confirm the presence of functional groups that might be responsible for the biosorption process. Peaks appearing in the spectrum (Figure 2) were assigned to various groups and bond in accordance with their respective wavenumber as reported in former literature. The region between $3100 \mathrm{~cm}^{-1}$ and $3600 \mathrm{~cm}^{-1}$ showed a broad and strong band stretch, indicative of the presence of $-\mathrm{NH}_{2}$ groups and free or hydrogen bonded $\mathrm{O}-\mathrm{H}$ groups [10] [11]. The light stretch at $2928 \mathrm{~cm}^{-1}$ showed the asymmetric $\mathrm{C}-\mathrm{H}$ vibration [12]. The peak at $1644 \mathrm{~cm}^{-1}$ was of $\mathrm{COO}^{-}, \mathrm{C}=\mathrm{O}$ and $\mathrm{C}-\mathrm{N}$ peptidic bond of proteins [12]. The peak at $1412 \mathrm{~cm}^{-1}$ was due to the symmetric bending of $\mathrm{CH}_{3}$ [13]. Band at $1236 \mathrm{~cm}^{-1}$ was assigned to $\mathrm{C}-\mathrm{O}$ vibration. The bands at $1080 \mathrm{~cm}^{-1}$ might be phosphonate $(\mathrm{P}-\mathrm{OH}$ stretching) [10] [14]. The bands at $770 \mathrm{~cm}^{-1}$ could be assigned to ester vibrations [15]. It was noted that the IR spectrum of Calotropis procera roots supported the presence of $\mathrm{O}-\mathrm{H}, \mathrm{COOH}, \mathrm{C}=\mathrm{O}, \mathrm{C}-\mathrm{N}, \mathrm{C}-\mathrm{H},-\mathrm{NH}_{2}, \mathrm{C}-\mathrm{O}$ and $\mathrm{POH}$ as functional groups. The diversity of functional groups indicated the complex nature of the biomass examined. This was similar to the earlier reports on functional groups of biomass [10] [14].
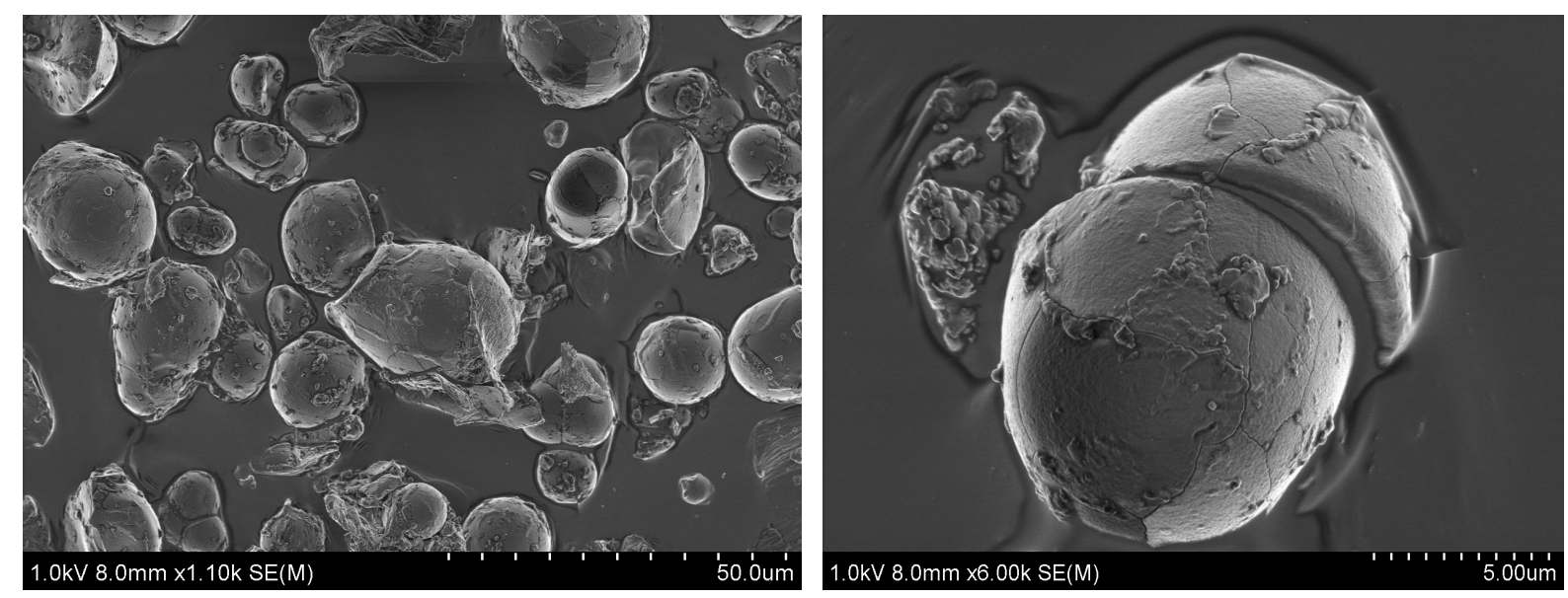

Figure 1. SEM of Calotropis procera roots. 


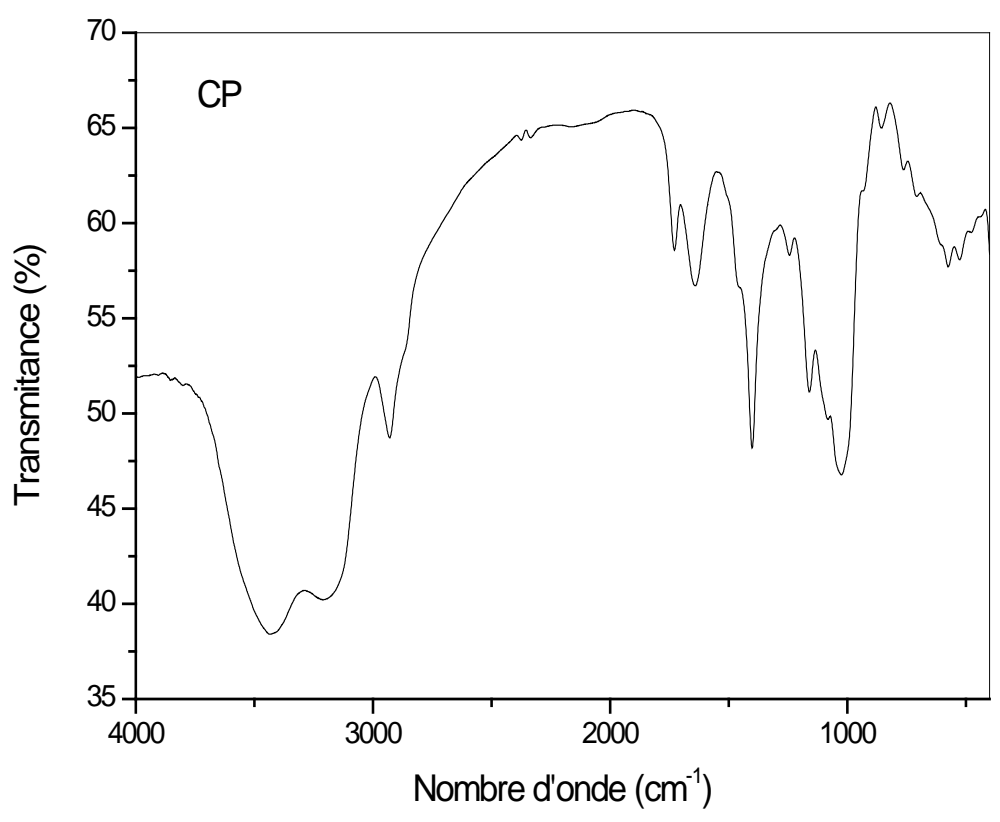

Figure 2. Infrared (IR) spectra of Calotropis procera roots.

The displacements of the corresponding bands $-\mathrm{OH},-\mathrm{NH}$ and carboxyl groups indicate the involvement of these groups in the biosorption of heavy metals by the roots of Calotropis procera.

\subsection{Effect of Initial Zn(II) Concentration on Metal Biosorption}

The metal distribution between the biomass and the aqueous solution at equilibrium is of importance in determining the maximum biosorption capacity of the biomass for $\mathrm{Zn}$ (II) ions. The effect of initial metal concentration on the biosorption capacity was investigated at $\mathrm{pH}$ 6.5. In Figure 3, biosorption of $\mathrm{Zn}(\mathrm{II})$ increased much quickly with increasing initial metal concentration from 10 to $500 \mathrm{mg} / \mathrm{l}$. A higher initial concentration provides an important driving force to overcome most partly of mass transfer resistance between the metal solution and Calotropis procera cell wall, and therefore the the biosorption capacity increases. In addition, the number of collisions between metal ions and the biosorbent increases with increasing initial metal concentration so the biosorption process is enhanced [16]. Biosorption rate was decreased with increasing initial concentration from 200 to $500 \mathrm{mg} / \mathrm{l}$ and this can be explained by the saturation of the biosorption sites on the biomass surface.

\subsection{Effect of $\mathrm{pH}$ on Metal Biosorption}

$\mathrm{pH}$ is an important parameter influencing heavy metal adsorption from aqueous solutions. It affects both the surface charge of adsorbent and the degree of ionization of the heavy metal in solution. The $\mathrm{pH}$ range of 1.5 6.5 was chosen, as the precipitation of $\mathrm{Zn}(\mathrm{II})$ is found to occur at $\mathrm{pH} \geq 7$ [17]. Variation of adsorption capacity of biomass for $\mathrm{Zn}$ (II) ions with $\mathrm{pH}$ is shown in Figure 4. The removal of metal ions from solution by adsorption is highly dependent on the $\mathrm{pH}$ of the solution. The biosorption of $\mathrm{Zn}$ (II) ions increases steadily with increase in intial $\mathrm{pH}$ and the maximum equilibrium biosorption capacity of $4.8 \mathrm{mg} / \mathrm{g}$ is observed at $\mathrm{pH} 6.5$ (natural $\mathrm{pH}$ of suspension).

\subsection{Effects of Interaction Time and Kinetics of Adsorption}

The biosorption of $\mathrm{Zn}$ (II) on CP roots as a function of contact time at $\mathrm{pH} 6.5$ is shown in Figure 5. The results indicated that the $\mathrm{Zn}(\mathrm{II})$ interacted with the biomass rapidly within the first $15 \mathrm{~min}$. Afterwards, the interactions slowed down and reached equilibrium in $40 \mathrm{~min}$.

Attainment of equilibrium is influenced by several factors including the nature of the adsorbent and the adsorbate, and the interactions between them. The kinetics of the interactions is thus likely to be dependent on different rate processes as the interaction time increases [18]. 


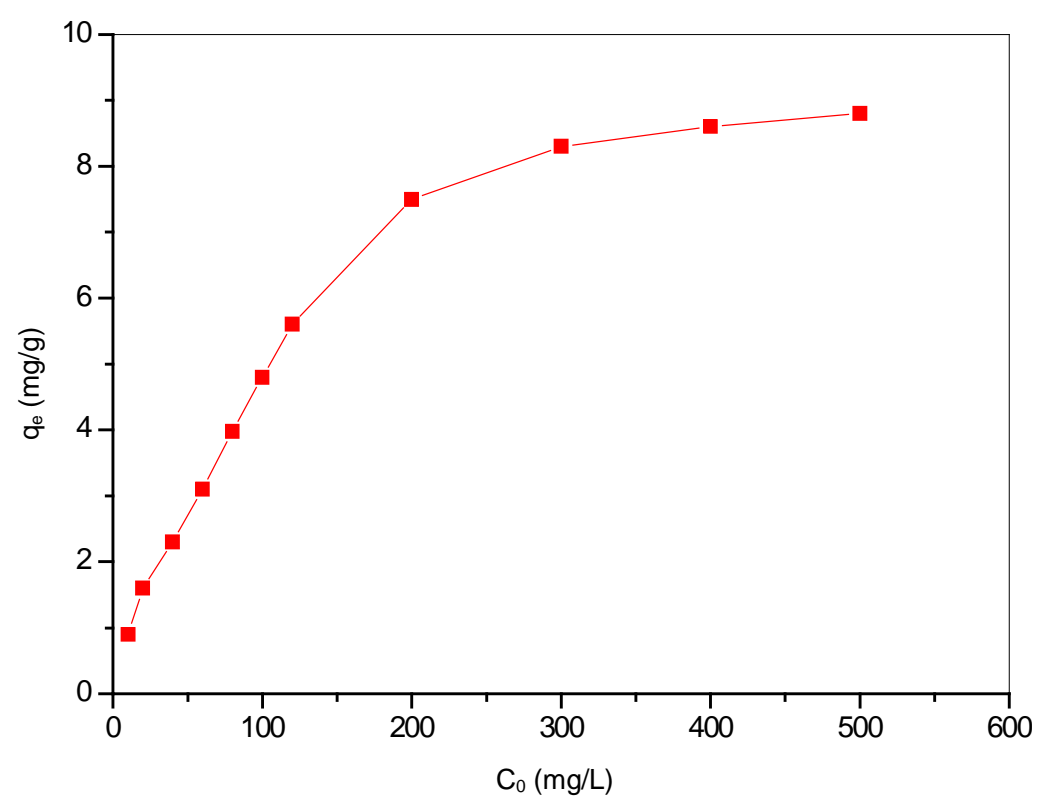

Figure 3. Effect of initial concentration of $\mathrm{Zn}(\mathrm{II})$ on biosorption capacity of Calotropis procera roots.

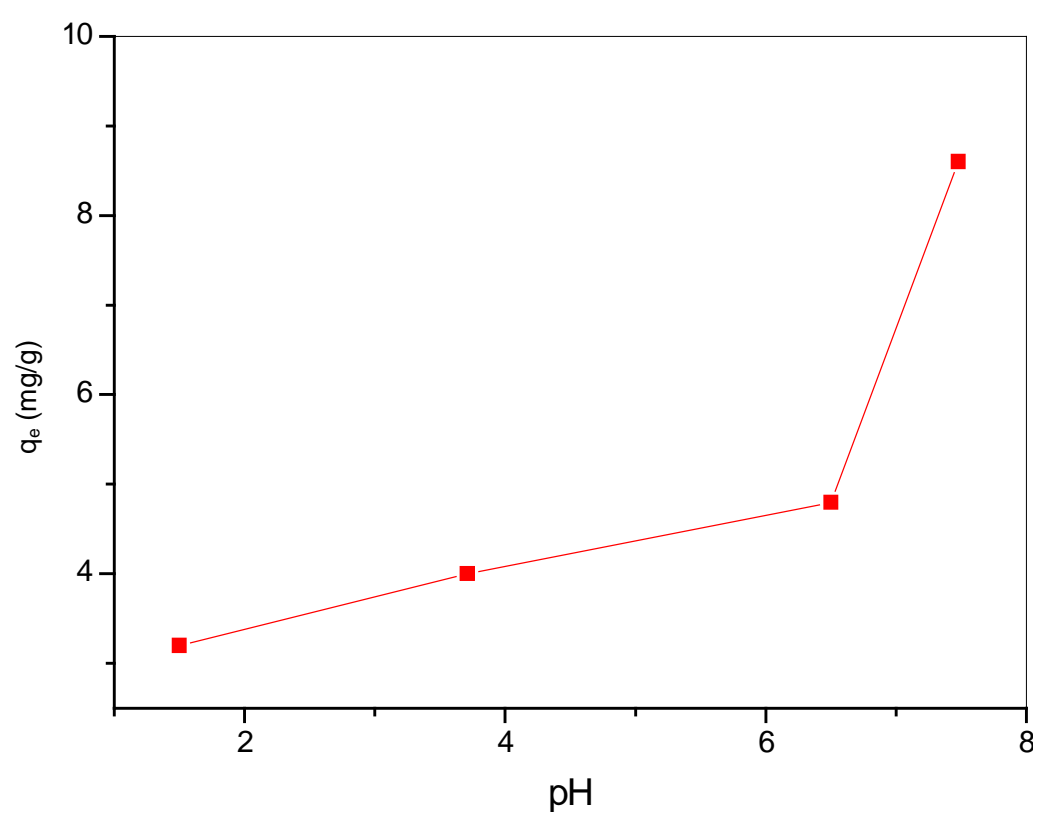

Figure 4. Effect of pH on biosorption of $\mathrm{Zn}(\mathrm{II})$ by Calotropis procera roots.

On the basis of this result, it can be observed that CP roots can be used to remove this metal ion.

Many models were used to describe the adsorption processes. The most appreciated was Pseudo second-order (Equation (3)) [19]:

$$
\frac{t}{q_{t}}=\frac{1}{2 k_{2} q_{e}^{2}}+\frac{1}{q_{e}} t
$$

where $q_{t}(\mathrm{mg} / \mathrm{g})$ is the amount of $\mathrm{Zn}(\mathrm{II})$ adsorbed at time $t(\mathrm{~min}), q_{e}(\mathrm{mg} / \mathrm{g})$ is the equilibrium adsorption capacity and $K_{2}(\mathrm{~g} /(\mathrm{mg} \cdot \mathrm{min}))$ is the pseudo-second-order rate constant of adsorption. The values of $K_{2}$ and $q_{e}$ calculated from the intercept and slope of equation are $0.28 \mathrm{~g} /(\mathrm{mg} \cdot \mathrm{min})$ and $4.80 \mathrm{mg} / \mathrm{g}$, respectively. 
Figure 6 shows a linear plot with very high value of the correlation coefficient $\left(R^{2}=1\right)$, in addition to the good agreement between experimental and calculated values of qe. Therefore, the adsorption of Zn(II) onto CP roots is greatly represented by the pseudo-second-order kinetics. In many cases, the second-order equation correlates well to the adsorption studies [20]. The applicability of second-order to the adsorption data indicates that the concentration of both CP roots and Zn(II) ions are involved in the rate determining step. Similar trends were shown for the adsorption of Zn(II) onto kaolin [8] and onto chitosan derivatives [21].

\subsection{Construction of Isotherms and Model Fitting}

Several adsorption isotherm models have been employed to interpret the adsorption behaviors of heavy metals on solid adsorbents. In this study, the data collected have been fitted to the Langmuir isotherm [22] and the

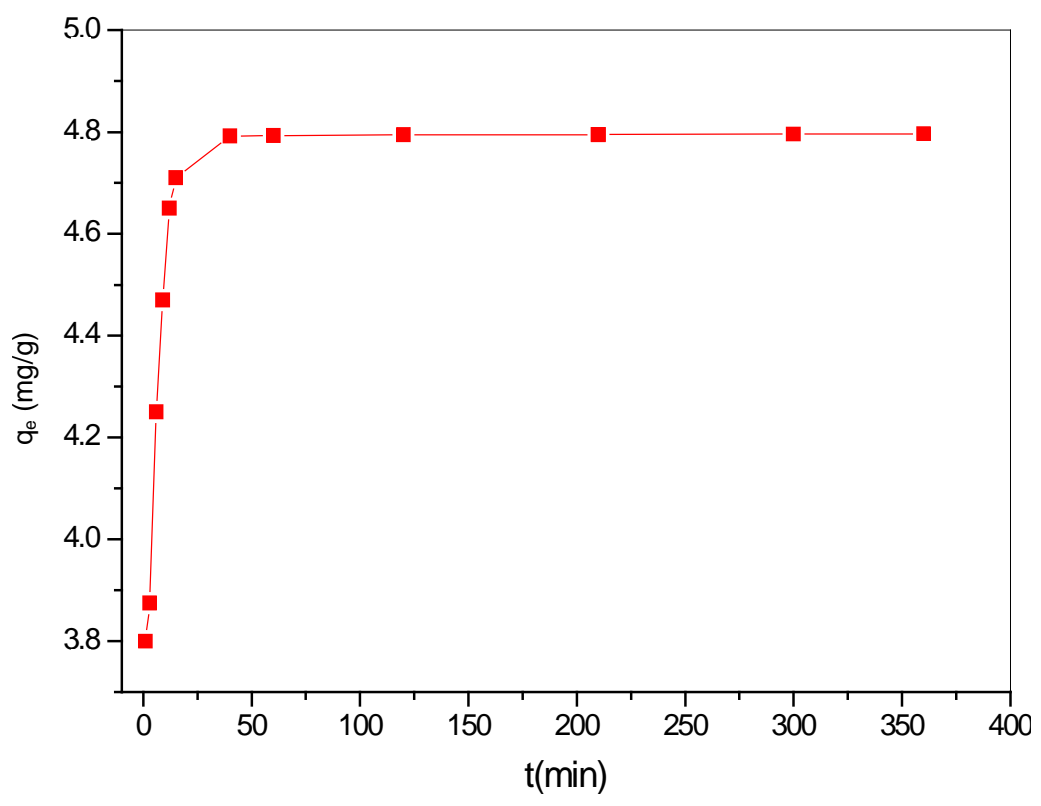

Figure 5. Effect of contact time on biosorption of $\mathrm{Zn}(\mathrm{II})$ by CP roots.

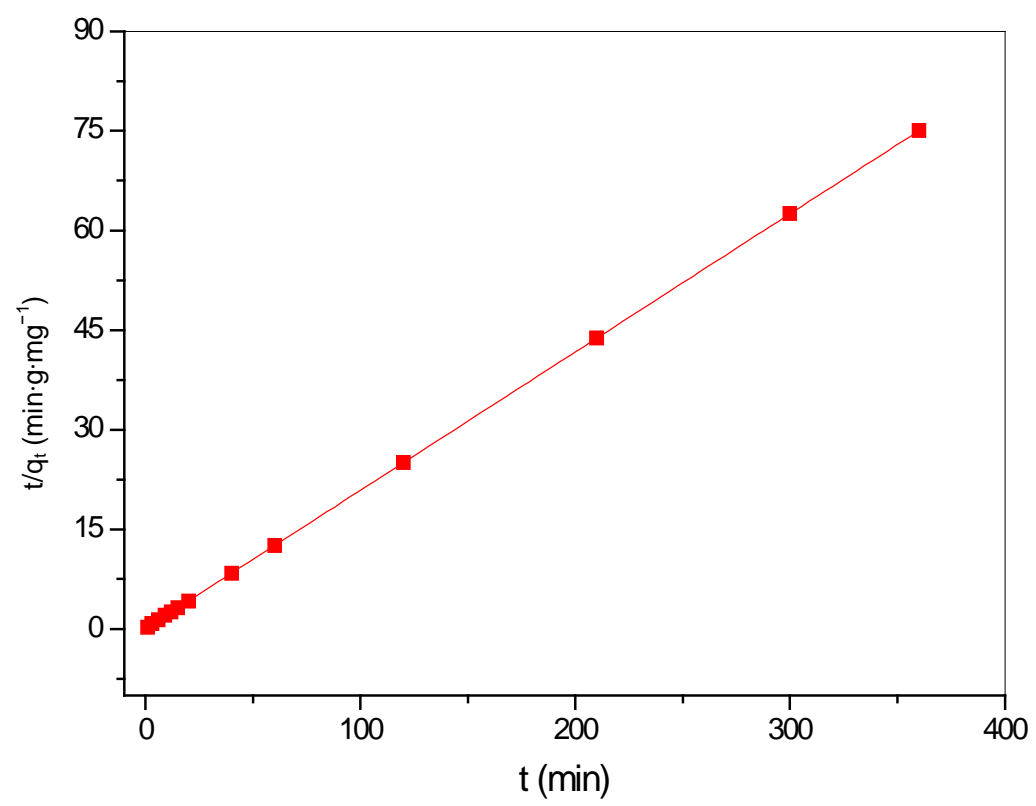

Figure 6. Lagergren pseudo second-order plots for $\mathrm{Zn}(\mathrm{II})$ biosorbed on CP roots. 
Freundlich isotherm [23], as described in Equations (4) and (5), respectively.

Langmuir equation

$$
\frac{C_{e}}{q_{e}}=\frac{C_{e}}{q_{m}}+\frac{1}{K_{L} q_{m}}
$$

Freundlich equation

$$
\ln q_{e}=\ln K_{f}+\left(\frac{1}{n}\right) \ln C_{e} \quad(5) \operatorname{lnq}_{\mathrm{e}}=\ln K_{\mathrm{F}}+\left(\frac{1}{n}\right) \ln C_{\mathrm{e}}(9)
$$

In these equations, $C_{e}$ is the concentration of $\mathrm{Zn}(\mathrm{II})$ in solution $(\mathrm{mg} / \mathrm{L})$ at equilibrium, $q_{e}$ is the amount of the adsorbed metal ions (mg/g) at the solid/liquid interface, $q_{\max }$ is the monolayer capacity of the adsorbent (mg/g), $K_{L}$ is the Langmuir adsorption constant $(\mathrm{L} / \mathrm{mg}), K_{f}$ and $1 / \mathrm{n}$ are empirical parameters, $K_{f}$ is the adsorption constant related to the bonding energy and $1 / \mathrm{n}$ is associated to the surface heterogeneity.

The sorption isotherms of metal ions on CP roots were fitted by two models, as shown in Figure 7 and Figure 8. The parameters predicted by the two different models are summarized in Table 1 . In general, parameters were fit using the linear adjustment and the correlation coefficient was fit better using the Langmuir model. The high value of $R^{2}$ as 0.991 indicated minimal deviation from the fitted equation showing that the adsorption data would follow Langmuir equation. Also, the data in Table 1 indicated that the maximum adsorption capacity of $\mathrm{CP}$ roots for $\mathrm{Zn}(\mathrm{II})$ was calculated as $9.69 \mathrm{mg} / \mathrm{g}$. It can be mentioned that the surface of CP roots is homogeneous and the adsorption of $\mathrm{Zn}(\mathrm{II})$ formed a monolayer on its outer surface [24]. Agouborde et al. [25] also, found the adsorption of some heavy metals such as $\mathrm{Zn}(\mathrm{II})$ onto sawdust and Brine sediments followed Langmuir model and formed monolayer with monolayer capacity $\left(q_{m}\right)$ of $2.58 \mathrm{mg} / \mathrm{g}$ and $4.85 \mathrm{mg} / \mathrm{g}$ respectively. Pehlivan et al. [26] found $q_{m}=0.176 \mathrm{mg} / \mathrm{g}$ with sugar beat pulp and $q_{m}=11.11 \mathrm{mg} / \mathrm{g}$ with fly ash. Other authors have reported a monolayer capacity of $1.66 \mathrm{mg} / \mathrm{g}$ for the adsorption of $\mathrm{Zn}(\mathrm{II})$ by Low rank Turkish coal [27] and 8.64 $\mathrm{mg} / \mathrm{g}$ by Granite [28]. It can be seen that CP roots are an effective adsorbent for $\mathrm{Zn}(\mathrm{II})$, when compared with some other adsorbents.

\section{Conclusion}

Biosorption technology, utilizing natural materials for effectively removing metals from aqueous media, offers an efficient alternative compared to traditional chemical and physical treatments. The goal of this work was to explore the potential use of Calotropis procera roots as a low-cost sorbent for removing Zn(II) ions from

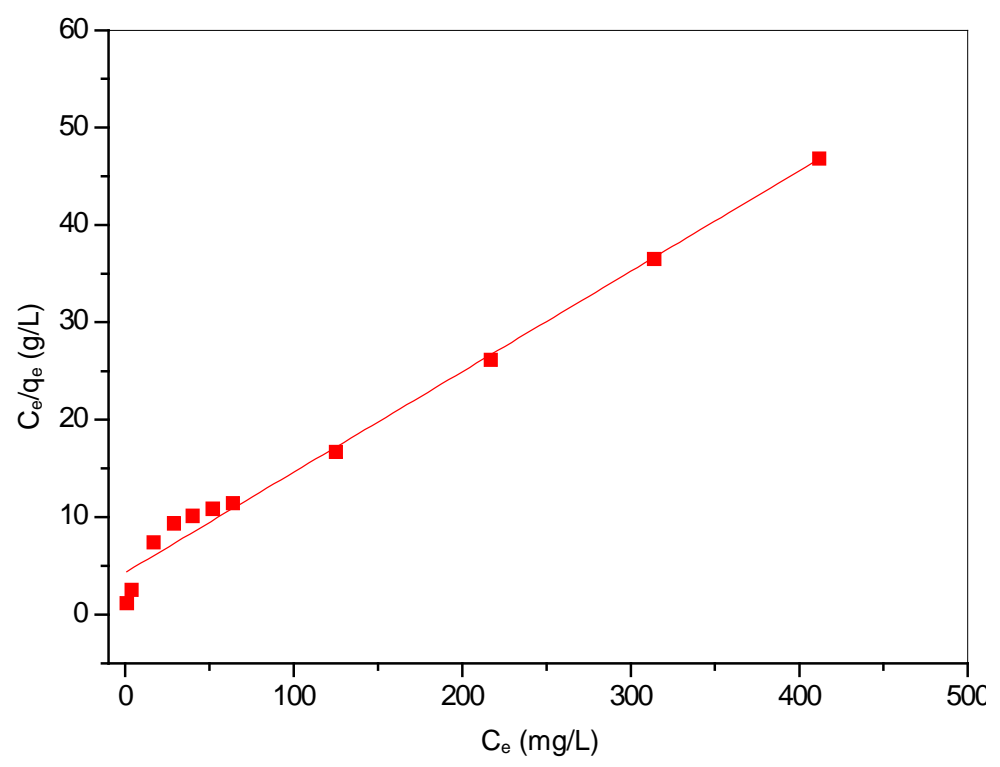

Figure 7. Langmuir isotherm plot for biosorption of $\mathrm{Zn}(\mathrm{II})$ on $\mathrm{CP}$ roots. 




Figure 8. Freundlich isotherm plot for biosorption of $\mathrm{Zn}(\mathrm{II})$ on CP roots.

Table 1. Langmuir and Freundlich parameters for biosorption of zinc on CP roots.

\begin{tabular}{crccccc}
\hline & \multicolumn{1}{c}{ Langmuir } & \multicolumn{3}{c}{ Freundlich } \\
\hline$q_{m}(\mathrm{mg} / \mathrm{g})$ & $\boldsymbol{K}_{L}(\mathbf{L} / \mathbf{g})$ & $\mathbf{R}^{2}$ & $\boldsymbol{n}$ & $\boldsymbol{K}_{f}$ & $\mathbf{R}^{2}$ \\
\hline $\mathbf{9 . 6 9}$ & 0.024 & $\mathbf{0 . 9 9 1}$ & 2.46 & 0.88 & $\mathbf{0 . 9 6 2}$ \\
\hline
\end{tabular}

aqueous solutions by batch design. The adsorption was found to be drastically depending on initial metal ion concentration, contact time and $\mathrm{pH}$ solution. The results gained from this study were well described by Langmuir model with monolayer capacity $q_{m}=9.69 \mathrm{mg} / \mathrm{g}$. Calotropis procera roots had a high adsorption capacity when compared with some other adsorbents reported in literature. This adsorption can be a good choice for removal of not only Zn(II) ions but also other heavy metal ions from waste water stream.

\section{References}

[1] Rahman, M.S. and Islam, M.R. (2009) Effects of pH on Isotherms Modeling for Cu(II) Ions Adsorption Using Maple Wood Sawdust. Chemical Engineering Journal, 149, 273-280. http://dx.doi.org/10.1016/j.cej.2008.11.029

[2] Volesky, B. and Holan, Z.R. (1995) Low Cost Biosorbent Rice Polish for the Removal of Lead(II) from Wastewaters. Biotechnology Progress, 11, 235-250. http://dx.doi.org/10.1021/bp00033a001

[3] Oyedepo, T.A. (2011) Biosorption of Lead (II) and Copper(II) Metal Ions on Calotropis procera (Ait.). Science Journal of Pure \& Applied Chemistry, Vol., 1-7.

[4] Kritikar, K.R. and Basu, B.D. (1999) Indian Medicinal Plants, Volume 3. 2nd Edition, International Book Distributors, Dehradun, 1610.

[5] Ogugua, C.A. and Muller, H.G. (1987) Cheese-Making Properties of Vegetable Rennet from Sodom Apple (Calotropis procera). Food Chemistry, 26, 71-79. http://dx.doi.org/10.1016/0308-8146(87)90168-3

[6] Kumar, S., Dewan, S., Sangraula, H. and Kumar, V.L. (2001) Anti-Diarrhoeal Activity of the Latex of Calotropis procera. Journal of Ethnopharmacology, 76, 115-118. http://dx.doi.org/10.1016/S0378-8741(01)00219-7

[7] Rerwez, A. and Mohd, A. (2009) Phytochemical Investigation of Calotropis procera Ait Roots. Indian Journal of Chemistry, 48, 443-446.

[8] Meroufel, B., Benali, O., Benyahia, M., Zenasni, M.A., Merlin, A. and George, B. (2013) Removal of Zn(II) from Aqueous Solution onto Kaolin by Batch Design. Journal of Water Resource and Protection, 5, 669-680. http://dx.doi.org/10.4236/jwarp.2013.57067 
[9] Zenasni, M.A., Benfarhi, S., Merlin, A., Molina, S., George, B. and Meroufel, B. (2012) Adsorption of Cu(II) on Maghnite from Aqueous Solution: Effects of $\mathrm{pH}$, Initial Concentration, Interaction Time and Temperature. Natural Science, 10, 856-868. http://dx.doi.org/10.4236/ns.2012.411114

[10] Sadhasivam, S., Savitha, S., Swaminathan, K. and Lin, F.H. (2009) Metabolically Inactive Trichoderma harzianum Mediated Adsorption of Synthetic Dyes: Equilibrium and Kinetic Studies. Journal of the Taiwan Institute of Chemical Engineers, 40, 394-402. http://dx.doi.org/10.1016/j.jtice.2009.01.002

[11] Saeed, A., Sharif, M. and Iqbal, M. (2010) Application Potential of Grapefruit Peel as Dye Sorbent: Kinetics, Equilibrium and Mechanism of Crystal Violet Adsorption. Journal of Hazardous Materials, 179, 564-572. http://dx.doi.org/10.1016/j.jhazmat.2010.03.041

[12] Gulnaz, O., Kaya, A. and Dincer, S. (2006) The Reuse of Dried Activated Sludge for Adsorption of Reactive Dye. Journal of Hazardous Materials, 134, 190-196. http://dx.doi.org/10.1016/j.jhazmat.2005.10.050

[13] Khaled, A., Nemr, A.E., El-Sikaily, A. and Abdelwahab, O. (2009) Removal of Direct N Blue-106 from Artificial Textile Dye Effluent Using Activated Carbon from Orange Peel: Adsorption Isotherm and Kinetic Studies. Journal of Hazardous Materials, 165, 100-110. http://dx.doi.org/10.1016/j.jhazmat.2008.09.122

[14] Lin, Y.H., He, X.B., Han, G.M., Tian, Q.J. and Hu, W.Y. (2011) Removal of Crystal Violet from Aqueous Solution Using Powdered Mycelial Biomass of Ceriporia lacerate P2. Journal of Environmental Sciences, 23, 2055-2062. http://dx.doi.org/10.1016/S1001-0742(10)60643-2

[15] Vieira, A.P., Santana, A.A., Bezerra, C.W.B., Silva, H.A.S., Chaves, J.A.P. and de Melo, J.C.P. (2009) Kinetics and Thermodynamics of Textile Dye Adsorption from Aqueous Solutions Using Babassu Coconut Mesocarp. Journal of Hazardous Materials, 166, 1272-1278. http://dx.doi.org/10.1016/j.jhazmat.2008.12.043

[16] Aksu, Z. and Tezer, S. (2005) Biosorption of Cadmium (II) from Aqueous Solutions by Pretreated Biomass of Marine Algae Durvillaea potarotum. Process Biochemisry, 40, 1347-1361. http://dx.doi.org/10.1016/j.procbio.2004.06.007

[17] Waychunas, G.A., Fuller C.C. and Davis, J.A. (2002) Surface Complexation and Precipitate Geometry for Aqueous Zn(II) Sorption on Ferrihydrite I: X-Ray Absorption Extended Fine Structure Spectroscopy Analysis. Geochimica et Cosmochimica Acta, 66, 1119-1137. http://dx.doi.org/10.1016/S0016-7037(01)00853-5

[18] Meroufel, B., Benali, O., Benyahia, M., Benmoussa, Y. and Zenasni, M.A. (2013) Adsorptive Removal of Anionic Dye from Aqueous Solutions by Algerian Kaolin M.A.: Characteristics, Isotherm, Kinetic and Thermodynamic Studies. Journal of Materials and Environmental Science, 4, 482-491.

[19] Zenasni, M.A., Meroufel, B., Merlin, A. and George, B. (2014) Adsorption of Congo Red from Aqueous Solution Using CTAB-Kaolin from Bechar Algeria. Journal of Surface Engineered Materials and Advanced Technology, 4, 332-341. http://dx.doi.org/10.4236/jsemat.2014.46037

[20] Ho, Y.S. (2006) Review of Second-Order Models for Adsorption Systems. Journal of Hazardous Materials, 136, 681689. http://dx.doi.org/10.1016/j.jhazmat.2005.12.043

[21] Ding, P., Huang, K.L., Li, G.Y., Liu, Y.F. and Zeng, W.W. (2006) Kinetics of Adsorption of Zn(II) Ion on Chitosan Derivatives. International Journal of Biological Macromolecules, 39, 222-227. http://dx.doi.org/10.1016/j.ijbiomac.2006.03.029

[22] Langmuir, I. (1918) The Adsorption of Gases on Plane Surfaces of Glass, Mica and Platinum. Journal of the American Chemical Society, 40, 1361-1403. http://dx.doi.org/10.1021/ja02242a004

[23] Freundlich, H. (1906) Über die adsorption in lösungen. Zeitschrift für Physikalische Chemie (Leipzig), 57, 385-470.

[24] Boamah, P.O., Zhang, Q., Hua, M., Huang, Y., Liu, Y., Wang, W. and Liu, Y. (2014) Lead Removal onto CrossLinked Low Molecular Weight Chitosan Pyruvic Acid Derivatives. Carbohydrate Polymers, 110, 518-527. http://dx.doi.org/10.1016/j.carbpol.2014.03.034

[25] Agouborde, L. and Navia, R. (2009) Heavy Metals Retention Capacity of a Non-Conventional Sorbent Developed from a Mixture of Industrial and Agricultural Wastes. Journal of Hazardous Materials, 167, 536-544. http://dx.doi.org/10.1016/j.jhazmat.2009.01.027

[26] Pehlivan, E., Cetin, S. and Yanik, B.H. (2006) Equilibrium Studies for the Sorption of Zinc and Copper from Aqueous Solutions Using Sugar Beat Pulp and Fly Ash. Journal of Hazardous Materials, 135, 193-199. http://dx.doi.org/10.1016/j.jhazmat.2005.11.049

[27] Karabulut, S., Karabaka, A., Deaizbi, A. and Yurcim, Y. (2000) Batch Removal of Copper(II) and Zinc(II) from Aqueous Solutions with Low Rank Turkish Coals. Separation and Purification Technology, 18, 177-184. http://dx.doi.org/10.1016/S1383-5866(99)00067-2

[28] Pérez-Novo, C., Fernández-Calviño, D. and Bermúdez-Couso, A. (2011) Phosphorus Effect on Zn Adsorption-Desorption Kinetics in Acid Soils. Chemosphere, 83, 1028-1034. http://dx.doi.org/10.1016/j.chemosphere.2011.01.064 